\title{
Binding Sites for Vascular Endothelial Growth Factor Are Localized on Endothelial Cells in Adult Rat Tissues
}

\author{
Lyn B. Jakeman, * Jane Winer, ${ }^{\ddagger}$ Gregory L. Bennett, ${ }^{\star}$ C. Anthony Altar, ${ }^{*}$ and Napoleone Ferrara \\ Departments of ${ }^{*}$ Endocrine Research, ${ }^{\ddagger}$ Cardiovascular Research, and ${ }^{\S}$ Medicinal and Analytical Chemistry, \\ Genentech, Inc., South San Francisco, California 94080
}

\begin{abstract}
Vascular endothelial growth factor (VEGF) is a secreted heparin-binding mitogen; its growth-promoting activity is limited to vascular endothelial cells in vitro and VEGF also stimulates angiogenesis in vivo. To identify target cells for VEGF and investigate the potential physiological role of this factor, iodinated recombinant human VEGF $\left({ }^{125}\right.$ I-rhVEGF) was used for in vitro ligand autoradiography on tissue sections from adult rats. ${ }^{125}$ I-rhVEGF exhibited saturable, displaceable binding to a single class of sites with high affinity and low capacity in all tissues and organs examined. Colocalization of ${ }^{125}$ I-rhVEGF binding with Factor VIII-like immunoreactivity demonstrated binding sites associated with vascular endothelial cells of both fenestrated and nonfenestrated microvessels and the endothelium of large vessels, while no displaceable binding was evident on nonendothelial cells. Specific binding was associated with quiescent as well as proliferating vessels. These findings support the hypothesis that VEGF plays a specific role in both the maintenance and in the induction of growth of vascular endothelial cells. (J. Clin. Invest. 1992. 89:244-253.) Key words: angiogenesis • growth factors • vascular permeability factor • endothelium • Factor VIII-like immunoreactivity
\end{abstract}

\section{Introduction}

Angiogenesis, the growth of new blood vessels, is required for the normal development and differentiation of the vascular tree as well as for organ repair after injury. However, if not properly controlled, angiogenesis can also represent a significant pathogenic component of tumor growth and metastasis, rheumatoid arthritis, or retinopathies $(1,2)$. Several growth factors, including epidermal growth factor (EGF), ${ }^{1}$ transform-

Address correspondence to Lyn B. Jakeman, Ph.D., Department of Neuroscience, Syntex Research, R7-101, 3401 Hillview Ave., Palo Alto, CA 94304.

Received for publication 14 June 1991 and in revised form 11 September 1991.

1. Abbreviations used in this paper: a and bFGF, acidic and basis fibroblast growth factor; EGF, epidermal growth factor; PD-ECGF, plateletderived-endothelial cell growth factor; PDGF, platelet-derived growth factor; rhVEGF, recombinant human vascular endothelial growth factor; TGF, transforming growth factor; TNF, tumor necrosis factor; VEGF, vascular endothelial growth factor.

J. Clin. Invest.

(c) The American Society for Clinical Investigation, Inc.

$0021-9738 / 92 / 01 / 0244 / 10 \$ 2.00$

Volume 89, January 1992, 244-253 ing growth factors (TGFs) $\alpha$ and $\beta$, tumor necrosis factor $\alpha$ (TNF $\alpha$ ), and angiogenin, can stimulate angiogenesis in vivo. Until recently, however, only the acidic and basic fibroblast growth factors (aFGF and bFGF) and platelet-derived endothelial cell growth factor (PD-ECGF) had been shown to act directly on endothelial cells to induce their proliferation (3-5). Nevertheless, the role of these three factors in the maintenance of the endothelium is not clear. The fibroblast growth factors are widely distributed and potently stimulate the proliferation of endothelial cells and other cell types. However, both FGFs and PD-ECGF lack a signal sequence and may be available to the endothelium only after trauma or cell death $(6,7)$.

Vascular endothelial growth factor (VEGF) is a dimeric heparin-binding protein with a molecular weight of $\sim 45,000$ that was isolated and purified from media conditioned by bovine pituitary folliculostellate cells (8). VEGF-like factors have also been identified from media conditioned by various normal and transformed cell types (i.e., 9-12). The amino acid sequence of VEGF is highly conserved across species and has homology with the A and B chains of platelet-derived growth factor (PDGF).

Several lines of evidence indicate that VEGF might have a specific role in the development and maintenance of blood vessels. VEGF exerts a potent mitogenic effect on vascular endothelial cells derived from both small and large vessels, while no proliferative effects are seen on a variety of other cell types in vitro (8). Also, VEGF can be secreted by intact cells, because its $\mathrm{NH}_{2}$ terminus is preceded by a typical signal sequence (13). Further evidence of a physiological role for VEGF has been suggested by in situ hybridization studies that have shown that the VEGF mRNA is widely distributed in vascularized organs and expressed at high levels in areas of active vascular proliferation. In the ovary, for example, a temporal relationship exists between VEGF mRNA expression and growth of capillary vessels in the corpora lutea $(14,15)$.

Recent studies have shown that ${ }^{125}$ I-VEGF can bind reversibly and with high affinity to sites on a variety of cultured endothelial cells (16-18) and also to sites on several transformed cell types that are not stimulated to proliferate by VEGF (19). However, cells in culture may exhibit different binding characteristics than in vivo, as many phenotypic and functional characteristics can be modified by conditions within the surrounding cellular environment (20). Therefore, to determine the distribution of cells that might respond to VEGF within the context of intact tissues, binding to tissue sections from adult rats was performed with biologically active, iodinated recombinant human VEGF ( ${ }^{125}$ I-rhVEGF). Quantitative autoradiography was used to examine the binding kinetics and simultaneously localize binding sites at both macroscopic and microscopic levels (21). 


\section{Methods}

Iodination of VEGF. Recombinant human VEGF (rhVEGF; 165 amino acid species) was purified (8) from media conditioned by transfected Chinese hamster ovary cells (13) and radiodinated by an indirect iodogen method (22). A volume of $20 \mu \mathrm{l} / 1.5 \mathrm{M} \mathrm{K}_{2} \mathrm{HPO}_{4}$ was added to a borosilicate tube coated with iodogen reagent (Pierce Chemical Co., Rockford, IL) and incubated with $1 \mathrm{mCi}$ of ${ }^{125} \mathrm{I} \mathrm{Na}$ (DuPont Co., Wilmington, DE) for $10 \mathrm{~min}$ at $4^{\circ} \mathrm{C}$. The mixture was transferred to a silated tube containing $10 \mu \mathrm{g}$ rhVEGF for $10 \mathrm{~min}$ before the reaction was quenched with $10 \mu \mathrm{l} n$-acetyl tyrosine ( $50 \mathrm{mM}$ in PBS) and $10 \mu \mathrm{l} \mathrm{Kl}$ $\left(1 \mathrm{M}\right.$ in $\left.\mathrm{dH}_{2} \mathrm{O}\right)$ and diluted in $200 \mu \mathrm{l}$ PBS. The labeled protein was purified by reverse-phase HPLC (Syncropac model $\mathrm{C}_{4}$; SynChrom. Inc., Lafayette, IN), and the concentration was approximated independently of biological activity by TCA precipitation. Nonprecipitable ${ }^{125}$ accounted for $<5 \%$ of the final preparation.

The radioligand was tested for its ability to promote growth of adrenal cortex capillary endothelial cells (23). Cells were plated at a density of $600 /$ well in microtiter plates in the presence of various concentrations of rhVEGF or ${ }^{125}$ I-rhVEGF. After 5 or $6 \mathrm{~d}$ cell densities were determined by a colorimetric acid phosphatase reaction (24).

Binding studies. Individual tissues were obtained from 10 adult male rats (Sprague-Dawley; 200-240 g; an additional 3 female rats were used for descriptive analysis of binding in ovary). After the rats were asphyxiated in $\mathrm{CO}_{2}$, fresh tissues were frozen in isopentane at $-15^{\circ} \mathrm{C}$ and were stored for up to $2 \mathrm{mo}$ at $-70^{\circ} \mathrm{C}$. Frozen sections were cut at $12 \mu \mathrm{m}$, thaw mounted onto gelatin-coated slides, and stored in air-tight boxes at $-70^{\circ} \mathrm{C}$ for no more than $4 \mathrm{mo}$. Fresh-frozen wholebody sections were prepared from 3 additional male rats as previously described (25). Sagittal sections of $25 \mu \mathrm{m}$ (LKB PMV 2250 Cryomicrotome; LKB Instruments, Inc., Gaithersburg, MD) were collected from 6-10 levels, mounted onto precooled cellophane tape and stored in airtight plastic bags at $-70^{\circ} \mathrm{C}$ for up to 2 mo.

After thawing, whole-body or tissue sections were preincubated for $3 \mathrm{~h}$ in DME supplemented with 10\% FCS (Gibco Laboratories, Grand Island, $\mathrm{NY}$ ), $25 \mathrm{mM}$ Hepes, $0.5 \mathrm{mM} \mathrm{MgCl}, 4 \mu \mathrm{g} / \mathrm{ml}$ leupeptin, and 5 nM PMSF (reagents from Sigma Chemical Co., St. Louis, MO; all incubations were done at $22^{\circ} \mathrm{C}$ ). The preincubation buffer was then removed and the sections were covered by a droplet of the same buffer containing 10-420 $\mathrm{pM}^{125} \mathrm{I}$-rhVEGF. Adjacent sections were incubated in the same concentration of ${ }^{125} \mathrm{I}$-rhVEGF with the addition of 2-2.5 $\mathrm{nM}$ rhVEGF to define nonspecific binding. Competition of binding in the presence of $1 \mathrm{pM}-500 \mathrm{nM}$ rhVEGF, $20 \mathrm{pM}-100 \mathrm{nM}$ PDGF, EGF or bFGF, or $\sim 100 \mathrm{pM}-100 \mu \mathrm{M}$ heparin was also examined (PDGF, EGF, and bFGF from Amgen Biologicals, Thousand Oaks, CA; heparin sodium salt from Sigma: $180 \mathrm{USP} / \mathrm{mg}$ ). After a 3-4-h incubation in a humidified chamber, all slides and sections were rinsed for $2 \mathrm{~s}$ in PBS containing $200 \mathrm{mM} \mathrm{NaCl}$ and $0.5 \mathrm{mM} \mathrm{MgCl}_{2}$, and then washed twice in the same buffer (10 min each). Slide-mounted sections were fixed for $10 \mathrm{~min}$ in $2 \%$ paraformaldehyde and $2 \%$ glutaraldehyde in $0.1 \mathrm{M}$ phosphate buffer ( $\mathrm{pH} 7.4$ ), rinsed for $2-5 \mathrm{~s}$ in $\mathrm{dH}_{2} \mathrm{O}$, and dried quickly with a stream of room-temperature air.

Binding characteristics were evaluated by quantitative autoradiography on kidney, brain, pancreas, or heart sections from 4-6 rats. Kinetics were determined using equilibrium saturation analysis (kidney and brain), association and dissociation kinetics (kidney), and competition analysis (kidney and brain) (26). Specificity competition studies were performed on sections from all four regions. For analysis, the dried sections and ${ }^{125}$ I standards (Amersham Corp., Arlington Heights, IL) were apposed to $\mathrm{x}$-ray film $\left({ }^{3} \mathrm{H}\right.$-Hyperfilm; Amersham) at $22^{\circ} \mathrm{C}$ for 3-12 d. The films were developed in Kodak D-19 (Eastman Kodak Co., Rochester, NY) and then analyzed with an RAS 3000 system (Amersham) by scaling measured optical density values to known standard activities using established methods $(27,28)$. Estimates of $\mathrm{EC}_{50}$ and $\mathrm{IC}_{50}$ values for binding were determined by iterative nonlinear regression analysis using a four-parameter fit (29). Scatchard analysis was performed using a modification of the computerized analysis program LIGAND (30).
Immunocytochemical staining and microscopy. After binding of ${ }^{125}$ I-rhVEGF and fixation for $30 \mathrm{~min}$ in $4 \%$ paraformaldehyde, slidemounted sections not used in quantitative analysis were stained with a polyclonal antiserum raised against human Factor VIII-related antigen to identify vascular endothelial cells $(31,32)$. The sections were washed for $10 \mathrm{~min}$ in PBS containing $500 \mathrm{mM} \mathrm{NaCl}$ (high salt buffer) and then for $30 \mathrm{~min}$ in $0.03 \% \mathrm{H}_{2} \mathrm{O}_{2}$. After preincubation for $1 \mathrm{~h}$ in $3 \%$ normal goat serum (Vector Laboratories, Inc., Burlingame, CA) sections were incubated in rabbit anti-human Factor VIII-related antigen (BioGenex Laboratories, San Ramon, CA; 1:50) for $15 \mathrm{~h}$ at $4^{\circ} \mathrm{C}$. The primary antibody was detected using the avidin-biotin peroxidase system (ABC; Vector Labs) with diaminobenzidine as the chromogen (33). The specificity of staining was confirmed by positive anatomical localization and by the lack of staining when either the primary or secondary antibodies were replaced by normal serum. After exposure to films or immunocytochemical staining, the glass slides were dipped for $3 \mathrm{~s}$ in Kodak NTB2 liquid emulsion (International Biotech, New Haven, CT; $1: 1$ with $\mathrm{dH}_{2} \mathrm{O}$ ). The slides were dried overnight and stored, with desiccant, at $4^{\circ} \mathrm{C}$ for $2-5 \mathrm{wk}$. The slides were developed with Kodak D-19 and counterstained with hematoxylin and eosin.
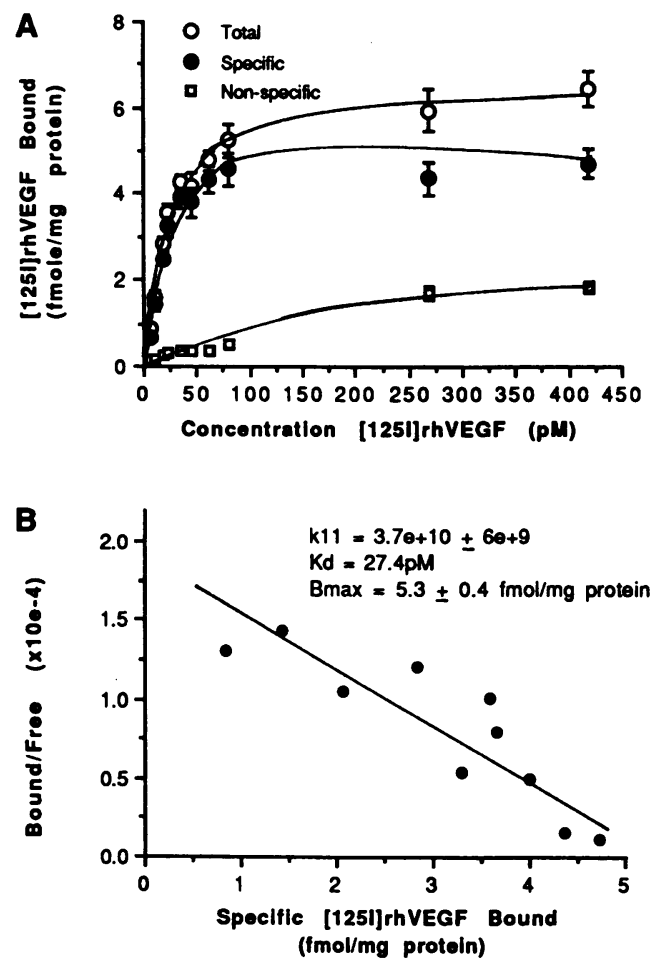

Figure 1. Quantitative analysis of binding to tissue sections. $(A)$ Saturation binding curves of ${ }^{125}$ I-rhVEGF to the kidney cortex in a single experiment $(n=6)$. To define total binding, tissue sections were incubated for $3 \mathrm{~h}$ in binding buffer containing $10-420$ pM ${ }^{125}$ I-rhVEGF. Nonspecific binding was determined on adjacent sections incubated in an identical concentration of ${ }^{125}$ I-rhVEGF with the addition of 2 $\mathrm{nM}$ rhVEGF. Values represent means $\mathbf{S E M}$. Similar curves were obtained with other regions of kidney as well as brain and pancreas sections. $(B)$ Scatchard analysis of binding data for the cortex region from a single kidney included in $A$. The binding data were fit by a model for a single class of binding sites. Similar individual and average values for $K_{\mathrm{d}}$ and $B_{\max }$ were observed in regions from kidney and brain sections (Table I) and in repeat experiments on these two organs using a different preparation of radioligand. Across all organs and experiments, the individual error estimates for $k_{11}\left(-\right.$ slope $\left.=1 / K_{d}\right)$ and $B_{\max }$ ranged from $18-46 \%$ and $8-34 \%$, respectively. 


\section{Results}

Characteristics of binding. Iodination of rhVEGF by the indirect iodogen method resulted in a range of specific activity of $1250-1660 \mathrm{Ci} / \mathrm{mmol}$ and retention of $73 \pm 6 \%$ of the maximal stimulation, or efficacy, of $\mathrm{rhVEGF}$ (mean \pm SEM for four independent assays). The half maximal concentration (potency) required for endothelial cell growth did not differ between the indirect iodogen prepared ${ }^{125} \mathrm{I}$-rhVEGF and rhVEGF $\left(\mathrm{EC}_{50}\right.$ $=27 \pm 7$ and $29 \pm 4 \mathrm{pM}$, respectively) indicating that the ${ }^{125} \mathrm{I}$-rhVEGF prepared by this method was biologically active.

Maximal binding of ${ }^{125} \mathrm{I}-\mathrm{rhVEGF}$ to tissue sections was established after incubation for $3 \mathrm{~h}$ with $75-100 \mathrm{pM}{ }^{125} \mathrm{I}-\mathrm{rh}$ VEGF. This binding was effectively blocked by the addition of $2 \mathrm{nM}$ rhVEGF to the incubation medium. The displaceable binding was saturable and accounted for $75-95 \%$ of the total binding over a range from 10-420 pM ${ }^{125}$ I-rhVEGF (Fig. $1 A$ ). Scatchard analysis of saturation isotherms in several regions from kidney and brain tissues revealed a single class of sites with high affinity $\left(K_{d}=27-35 \mathrm{pM}\right)$ and low capacity $(2.1-7.2$ $\mathrm{fmol} / \mathrm{mg}$ protein) (Table I; Fig. $1 B$ ). The $K_{\mathrm{d}}$ was also estimated by kinetic analysis of association and dissociation rates in kidney sections $\left(\mathrm{k}_{-1} / \mathrm{k}_{1}=11-21 \mathrm{pM}\right.$; Fig. 2). Approximation of the $K_{\mathrm{d}}$ was also confirmed by the displacement of $8 \mathrm{pM}{ }^{125} \mathrm{I}-\mathrm{rh}-$ VEGF $\left(<K_{d}\right)$ in kidney and brain tissues with 1 pM to $2 \mathrm{nM}$ rhVEGF, revealing estimates of 14,22 , and 24 pM in kidney cortex, papilla, and brain cortex, respectively.

Consistent with the biological activity of rhVEGF, no binding of ${ }^{125} \mathrm{I}-\mathrm{rh}$ VEGF was observed after pretreatment with $5 \mathrm{mM}$ dithiothreitol at $22^{\circ} \mathrm{C}$ for $1 \mathrm{~h}$ or preincubation for $2 \mathrm{~h}$ with a monoclonal antibody (34) that blocks the mitogenic activity of rhVEGF. A control monoclonal antibody directed against another recombinant human growth factor did not interfere with the binding of ${ }^{125} \mathrm{I}-\mathrm{rh}$ VEGF.

Purified rhVEGF competed for binding with the radioligand with equivalent potency $\left(\mathrm{IC}_{50}\right.$ for $75 \mathrm{pM}{ }^{125} \mathrm{I}$-rhVEGF $=58-70 \mathrm{pM}$ rhVEGF in brain, kidney, and pancreas sections)
(Fig. $3 \mathrm{~A}$ ). In contrast, the density of binding sites was not affected by the addition of up to $100 \mathrm{nM}$ of PDGF, EGF, or bFGF. Likewise, no decrease in total or nonspecific binding was observed in brain, pancreas, or heart sections when $\sim 100$ pM-100 $\mu \mathrm{M}$ heparin was added to the incubation medium (Fig. 3 B).

Distribution of binding sites. Incubation of whole body sections in 70-80 pM $^{125} \mathrm{I}-\mathrm{rhVEGF}$ revealed displaceable binding in all organs, with the highest levels in brain and spinal cord, adrenal cortex, glandular stomach, lung, spleen, and pancreas (Fig. 4). In these organs, the binding was displaced by $70-90 \%$ with the addition of $2.5 \mathrm{nM}$ rhVEGF to the incubation medium. Throughout the sections, specific binding was heterogeneously distributed in a manner consistent with the known vascular pattern of most tissues $(35,36)$.

The distribution of ${ }^{125}$ I-rhVEGF binding sites was then examined with higher resolution by emulsion autoradiography of slide-mounted sections. Binding and immunocytochemical staining with antiserum to Factor VIII-related antigen were performed on the same sections (Fig. 5-8).

In the central nervous system, ${ }^{125}$ I-rhVEGF binding sites were associated with Factor VIII immunoreactivity in arteries, veins, and microvessels (Fig. $5 A-D$ ). The density of binding was greatest in the gray matter of the brain and spinal cord (see also Table I). In the cerebral cortex, the binding pattern followed the distribution of penetrating vessels extending from the outer meninges toward the deeper laminae. Displaceable binding was also associated with the meninges and the large vessels on the surface of the brain and spinal cord, and was seen along vascular elements in the choroid plexus. No binding was seen along the ependyma of the ventricles. Examination of pituitary sections revealed binding in the pars distalis and pars nervosa, while essentially no binding was seen in the poorly vascularized pars intermedia.

Heart sections (Fig. 6) exhibited a diffuse pattern of displaceable binding sites throughout the atrial and ventricular myocardium. At higher magnification, this binding was colocalized

Table I. Affinity and Capacity of Binding of ${ }^{125}$ I-rhVEGF to Kidney Cortex, Outer Medulla, and Papilla $(n=6)$, and Brain Cerebral Cortex and Corpus Callosum $(n=4)$

\begin{tabular}{|c|c|c|c|c|c|c|c|c|c|c|}
\hline Region & $K_{d}$ & $K_{11}$ & S.E. & $B_{\max }$ & S.E. & $k_{-1}$ & $k_{1}$ & $k_{-1} / k_{1}$ & $\mathrm{IC}_{30}$ & Hill \\
\hline & $p M$ & \multicolumn{2}{|c|}{$\times 10^{10}$} & \multicolumn{2}{|c|}{ fmol/mg prot } & $\times 10^{-2}$ & $\times 10^{-4}$ & $p M$ & $p M$ & \\
\hline \multicolumn{11}{|l|}{ Kidney } \\
\hline Cortex & $29.4 \pm 4$ & $3.7 \pm 0.5$ & $1.2 \pm 0.3$ & $5.7 \pm 2.5$ & $1.0 \pm 0.2$ & 1.3 & 2.7 & 21 & $14 \pm 1$ & 0.73 \\
\hline Medulla & $27.3 \pm 4$ & $3.9 \pm 0.6$ & $1.3 \pm 0.1$ & $3.8 \pm 0.4$ & $0.7 \pm 0.1$ & 0.9 & 1.3 & 20 & - & - \\
\hline Papilla & $29.4 \pm 4$ & $3.6 \pm 0.4$ & $1.3 \pm 0.1$ & $7.2 \pm 0.3$ & $1.4 \pm 0.3$ & 1.4 & 1.6 & 11 & $22 \pm 2$ & 0.71 \\
\hline \multicolumn{11}{|l|}{ Brain } \\
\hline Cortex & $35.3 \pm 3$ & $2.8 \pm 0.3$ & $0.9 \pm 0.1$ & $5.1 \pm 0.3$ & $0.9 \pm 0.1$ & - & - & - & $24 \pm 16$ & 0.54 \\
\hline Corpus callosum & $32.3 \pm 6$ & $3.4 \pm 0.6$ & $1.4 \pm 0.2$ & $2.1 \pm 0.1$ & $0.3 \pm 0.1$ & - & - & - & - & - \\
\hline
\end{tabular}

Saturation kinetics revealed a single class of binding sites in all tissues, with $K_{\mathrm{d}}$ values ranging from 27 to $36 \mathrm{pM}$, and $B_{\max }$ values ranging from 2.1 to $7.2 \mathrm{fmol} / \mathrm{mg}$ protein (ex. Fig. 1). $K_{11}=$-slope from scatchard $\left(1 / K_{\mathrm{d}}\right)$. S.E. represents the average and SEM of estimates of errors for individual determinations in each region. Values represent mean \pm SEM for sections from $(n)$ animals in a single experiment. Although results of a single experiment are shown for each tissue, all experiments were performed two times with different preparations of ${ }^{125}$ I-rhVEGF, and similar results were obtained. $k_{-1}$ (association constant) and $k_{1}$ (dissociation constant) were used in determination of $K_{d}$ by kinetic constants in kidney sections $(n=3)$. The association of displaceable binding of $100 \mathrm{pM}^{125} \mathrm{I}$-rhVEGF to kidney cortex, medulla, and inner medulla increased up to $3 \mathrm{~h}$; no additional binding was seen at $6 \mathrm{~h}$ (Fig. 2). The dissociation of ${ }^{125} \mathrm{I}$-rhVEGF from these regions was determined by washing sections, after equilibrium had been reached, in a larger volume (4 slides/15 ml) of $2 \mathrm{nM}$ rhVEGF for $0.1-38$ hours. $K_{d}$ estimated by $\mathrm{IC}_{50}$ values as determined in kidney cortex and brain cortex by the competition of $8 \mathrm{pM}^{125} \mathrm{I}-\mathrm{rhVEGF}$ with $1 \mathrm{pM}$ to $2 \mathrm{nM}$ rhVEGF. 

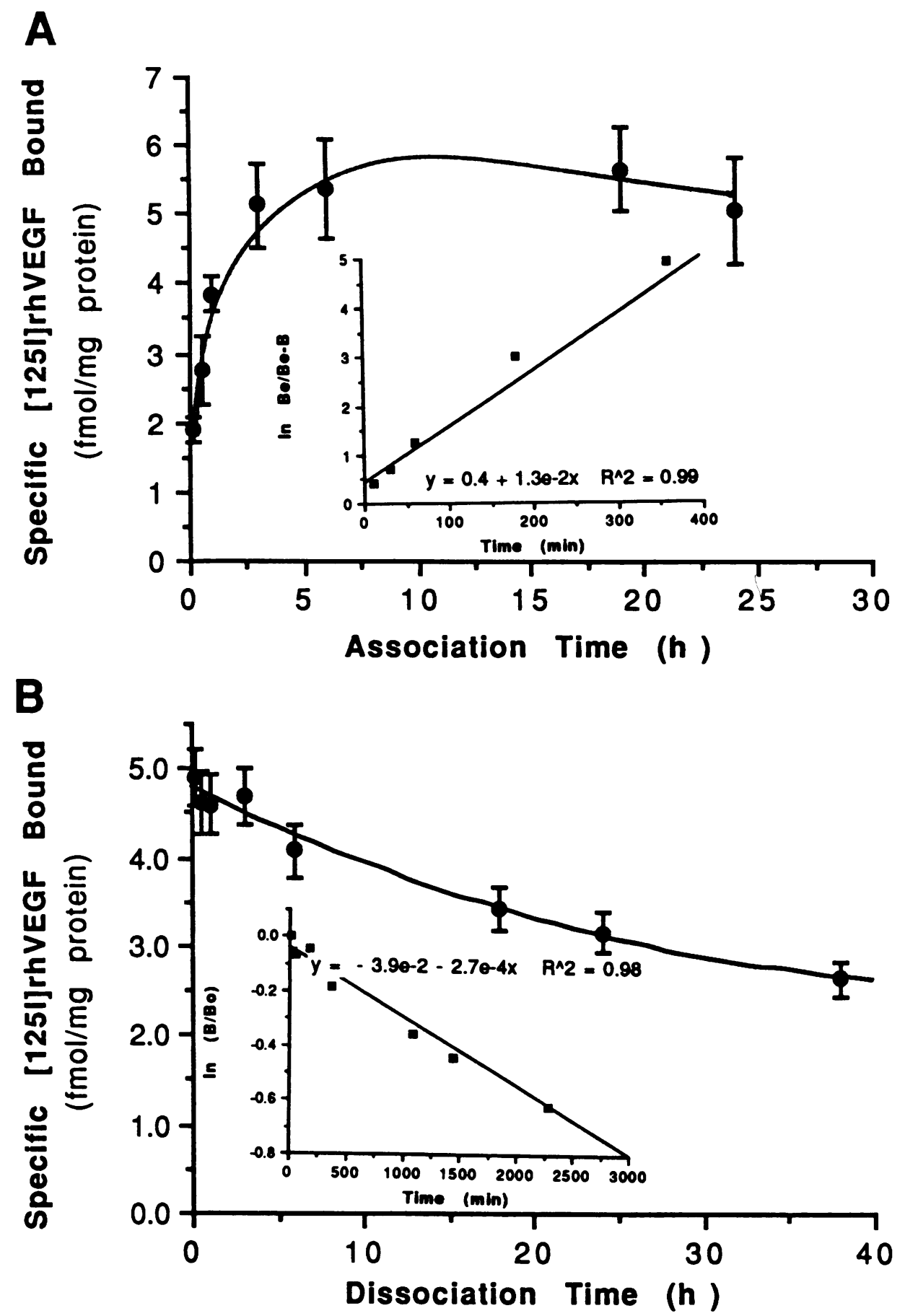

Figure 2. Association $(A)$ and dissociation $(B)$ curves for binding of 100 pM ${ }^{125}$ I-rhVEGF to cortex region of sections from rat kidney. Values represent means \pm SEM for binding to three kidney sections in a single experiment. $K_{-1}$ and $K_{1}$ were determined by a linear fit using means at each time point, and are reported for three regions of kidney in Table $I$.

with Factor VIII immunoreactive cells lining microvessels and larger coronary vessels. The most striking region was the intense binding distributed along the endothelial lining of the heart valves and the aorta, and pulmonary artery and vein. Binding was also associated with the vessels within the tunica adventitia supplying the aortic wall (vasa vasorum). In contrast, displaceable binding to smooth muscle cells in the media was not evident (Fig. 6, $E$ and $F$ ).

Lung tissue sections (not shown) exhibited very high binding density and intense staining with Factor VIII antiserum. Displaceable binding sites were found on the luminal surface of large vessels and also in association with the distal bronchiole tree and alveoli, where capillaries involved in gas exchanges are localized. In contrast, binding and Factor VIII-like staining were both distinctly absent along the epithelial lining of the bronchi.

In the liver and pancreas, binding and Factor VIII immunoreactivity were colocalized along the lining of larger vessels, including the hepatic vein, hepatic artery, and portal branches (Fig. 5, $E$ and $F$ ), and the large arteries and veins in the pancreas. Intense binding was also evident throughout the small vessels of both organs, although Factor VIII immunoreactivity was very light in these smaller vessels.

In the kidney cortex, binding and Factor VIII-like immunoreactivity were most intense in the glomeruli, and the staining pattern reflected the distribution of fenestrated capillaries 
A

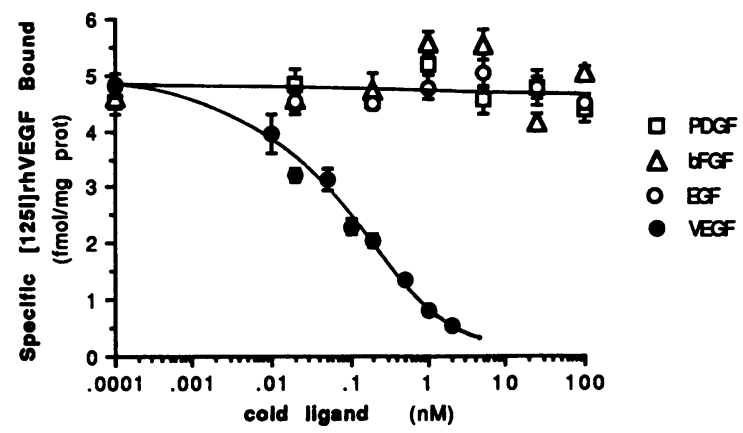

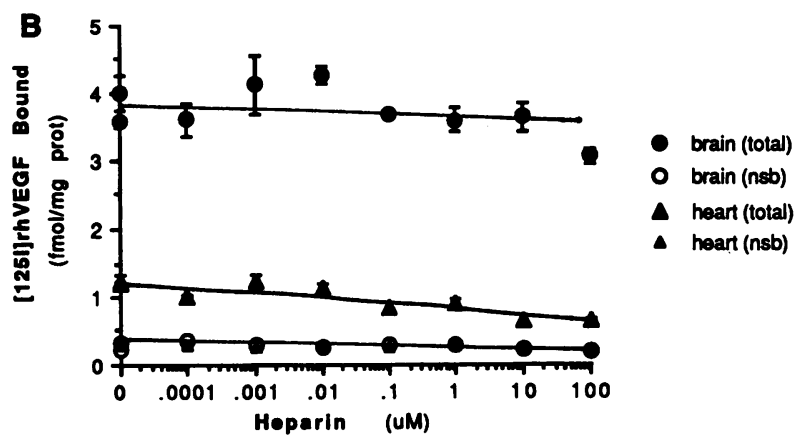

Figure 3. Competition of binding with ${ }^{125} \mathrm{I}-\mathrm{rhVEGF}$. $(A)$. Sections of rat brain $(n=4)$ were incubated in binding buffer containing 85 pM ${ }^{125} \mathrm{I}-$ rhVEGF and 20 pM-100 nM rhVEGF, basic FGF, PDGF, or EGF. rhVEGF competed for binding in cerebral cortex with similar potency $\left(\mathrm{IC}_{50}=59 \pm 3 \mathrm{pM} ;\right.$ mean $\left.\pm \mathrm{SEM}\right)$. Similar values were obtained from sections of pancreas $\left(\mathrm{IC}_{50}=58 \pm 12 \mathrm{pM} ; n=4\right)$ and kidney cortex $\left(\mathrm{IC}_{50}\right.$ $=72 \pm 13 \mathrm{pM} ; n=4)$. (B) Sections of brain and heart $\left(n=4\right.$ and $n=2$, respectively) were incubated in buffer containing 82 pM ${ }^{125}$ I-rhVEGF and $\sim 100 \mathrm{pM}-100 \mu \mathrm{M}(180 \mathrm{U} / \mathrm{mg})$ heparin. Values represent mean \pm SEM. Differences in total and nonspecific binding were evaluated by analysis of variance and compared to control (no heparin) using Dunnett's two-tailed posthoc test. No significant differences in binding were found at any heparin concentration tested.

within these structures (Fig. 7). Other binding in the cortex exhibited a sinusoidal distribution that also corresponded with Factor VIII immunoreactivity in the cortical labyrinth. In the medulla, binding was concentrated within the vascular rays. The most intense binding in the kidney was found within the highly vascularized papilla. In the adrenal gland, high levels of binding sites were evident in association with sinusoids in the cortex. Binding within the medulla was associated with large vessels and bundles that stained positively with the Factor VIII antiserum.
In contrast with most organs and tissues in adult animals, where the endothelium is quiescent, follicular development in the ovary is accompanied by an active cycle of angiogenesis during luteal development and vascular degeneration during its regression (37). The binding patterns observed in ovary sections from normally cycling rats reflected this dynamic vascular environment (Fig. 8). In the central medulla region, displaceable binding was found in association with numerous blood vessels. In secondary and mature follicles, binding was absent within the granulosa cell region. Binding was evident in the
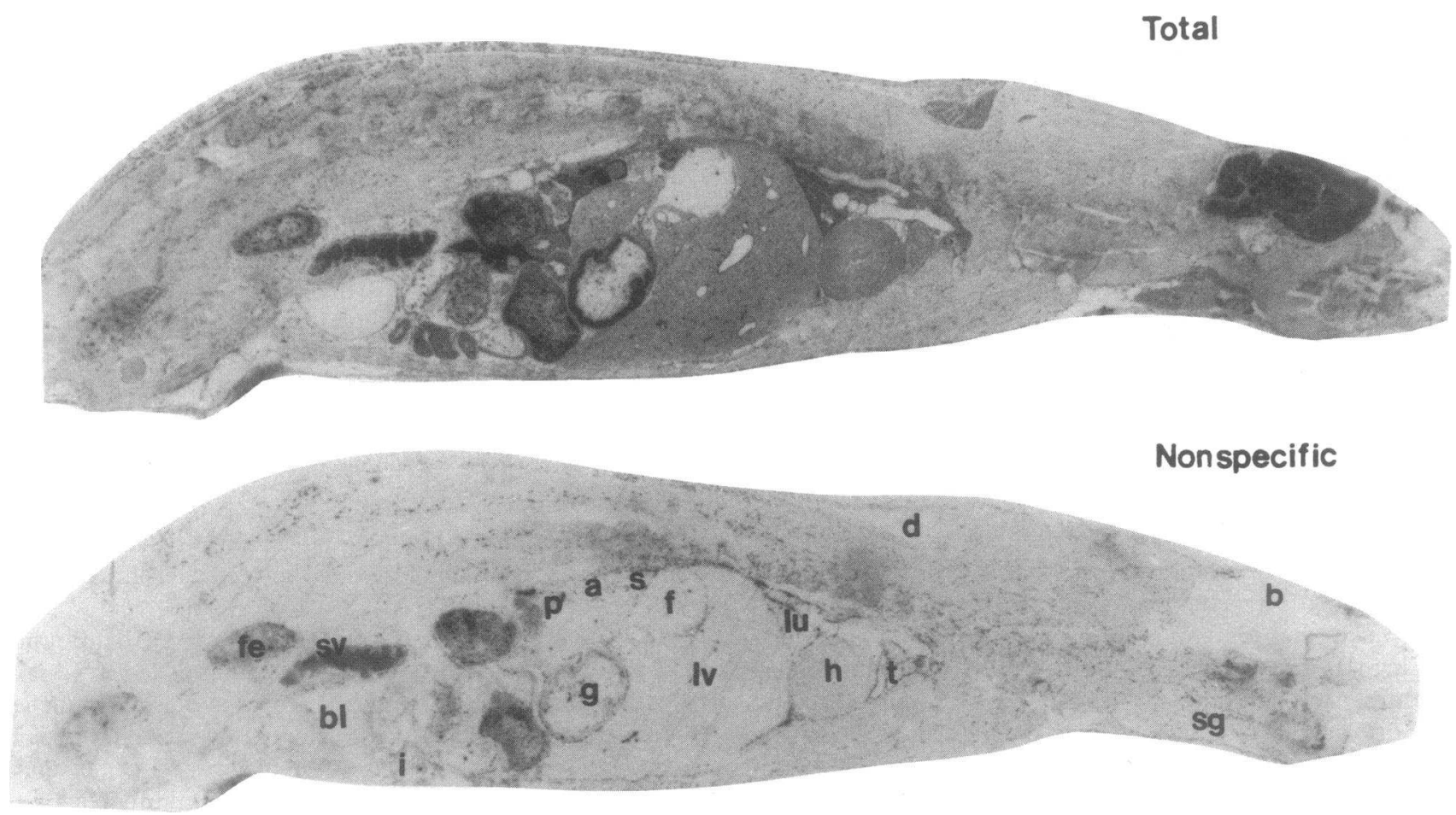

Figure 4. ${ }^{125} \mathrm{I}$-rhVEGF binding in whole body sections. Total binding (top) was determined after incubation in 88 pM ${ }^{125} \mathrm{I}$-rhVEGF. Nonspecific binding (bottom) was defined in an adjacent section in the presence of $2.5 \mathrm{nM}$ rhVEGF. $b$, Brain; sg, submaxillary gland; $d$, dorsal fat gland; $t$, thymus; $h$, heart; $l u$, lung; $l v$, liver; $f$, fundus of stomach; $s$, spleen; $a$, adrenal gland; $p$, pancreas; $g$, glandular stomach; $i$, intestine; $b l$, bladder; $s v$, seminal vesicle; $f e$, fecal remains. 

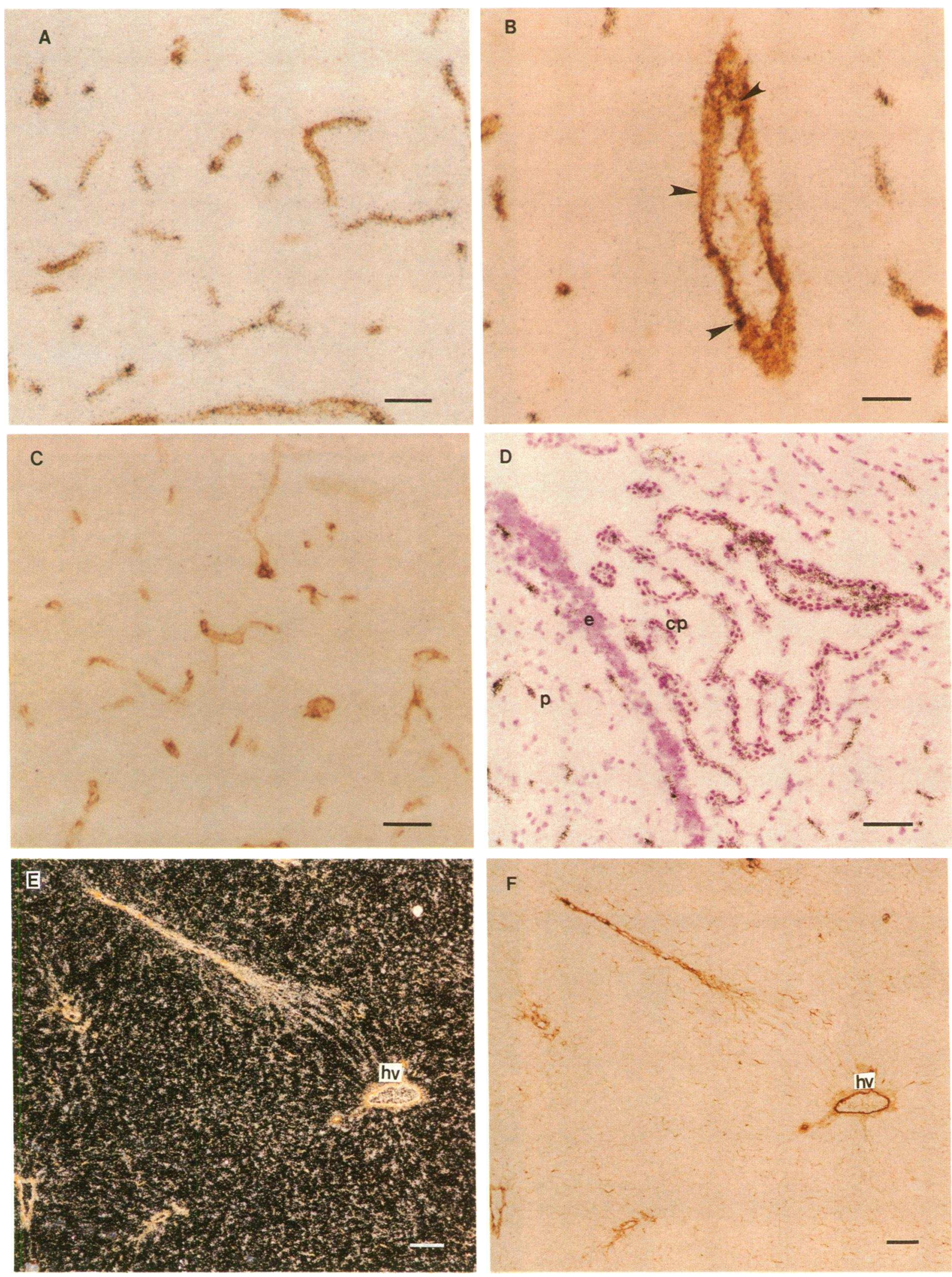

Figure 5. Binding sites and Factor-VIII immunoreactivity in brain and liver sections. $(A)$ Colocalization of ${ }^{125}$ I-rhVEGF binding sites (black-silver grains) and Factor VIII-like immunoreactivity (brown reaction product) on microvessels from adult rat brain $(\mathrm{scale}$ bar $=50 \mu \mathrm{m})$. $(B) \mathrm{Higher}$ magnification shows binding associated with Factor VIII immunoreactive cells lining a larger vessel in the brain (arrowheads; scale bar $=25 \mu \mathrm{m})$. $(C)$ Binding sites are displaced from Factor VIII-positive elements with the addition of $2 \mathrm{nM}$ rhVEGF to the incubation medium (scale bar $=50 \mu \mathrm{m}) .(D)$ Binding sites are found on microvessels within the parenchyma of the brain $(p)$ and within the choroid plexus ( $c p)$. No binding is seen on the ependymal lining of the ventricle $(e)($ scale bar $=50 \mu \mathrm{m}) .(E)$ Dark-field photomicrograph illustrates binding associated with large vessels of the liver, including the hepatic vein $(h v)$, as well as the sinusoidal endothelium. $(F)$ Factor VIII-like immunoreactivity in an adjacent section of liver (scale bar for $E$ and $F=100 \mu \mathrm{m}$ ). 

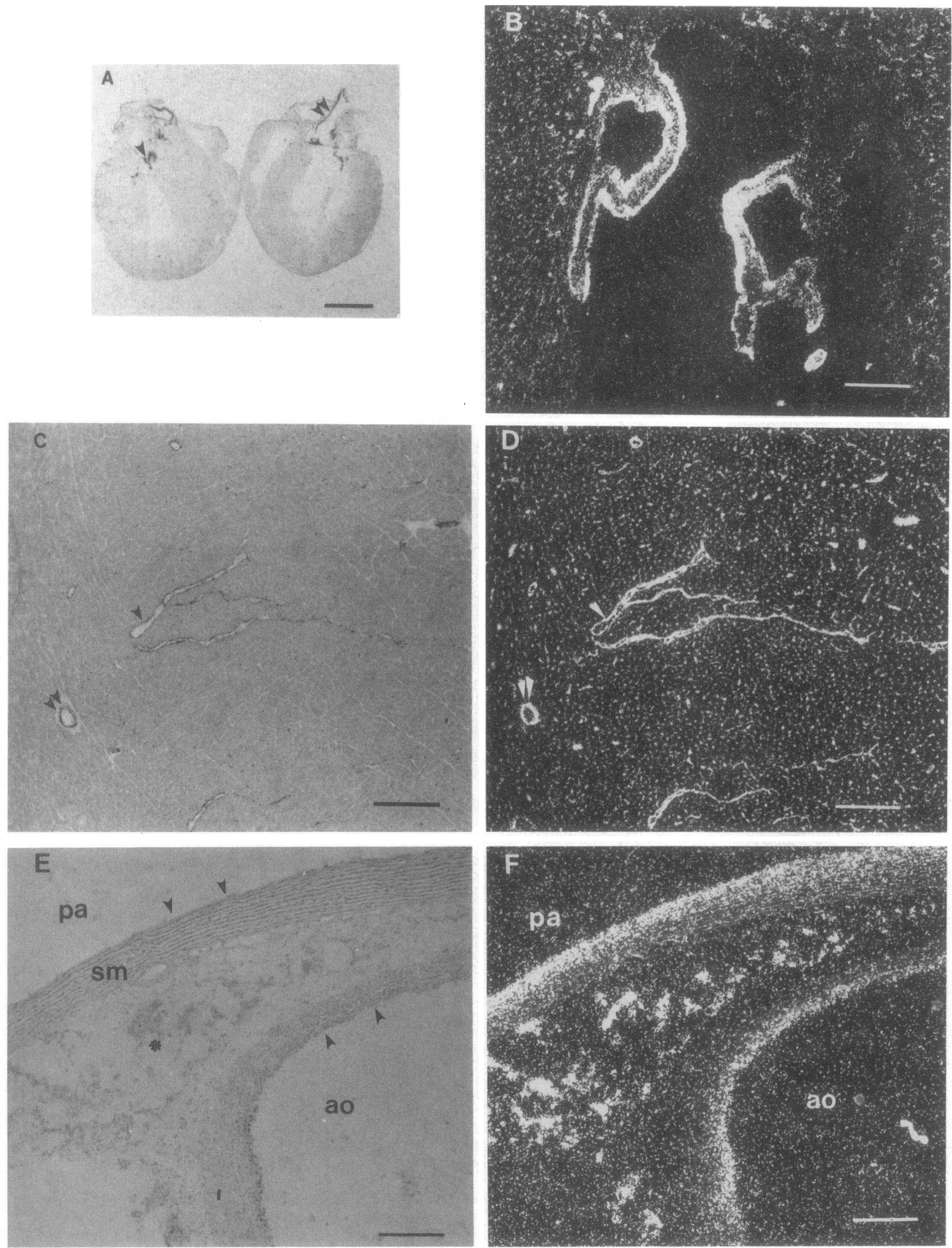

Figure 6. Specific ${ }^{125}$ I-rhVEGF binding to vascular endothelium in heart and aorta. $(A)$ Dry-film autoradiograph of sections from two rat hearts Diffuse binding is associated with the myocardium, and more intense binding is seen on the valves (single arrowheads) and along the aorta (double arrowhead; scale bar $=20 \mathrm{~mm}$ ). (B) Dark-field photomicrograph of ${ }^{125}$ I-rhVEGF binding to the mitral valve of the heart. This binding was found the upper and lower surfaces of all of the valves of the heart, as determined by examination of longitudinal sections through the 

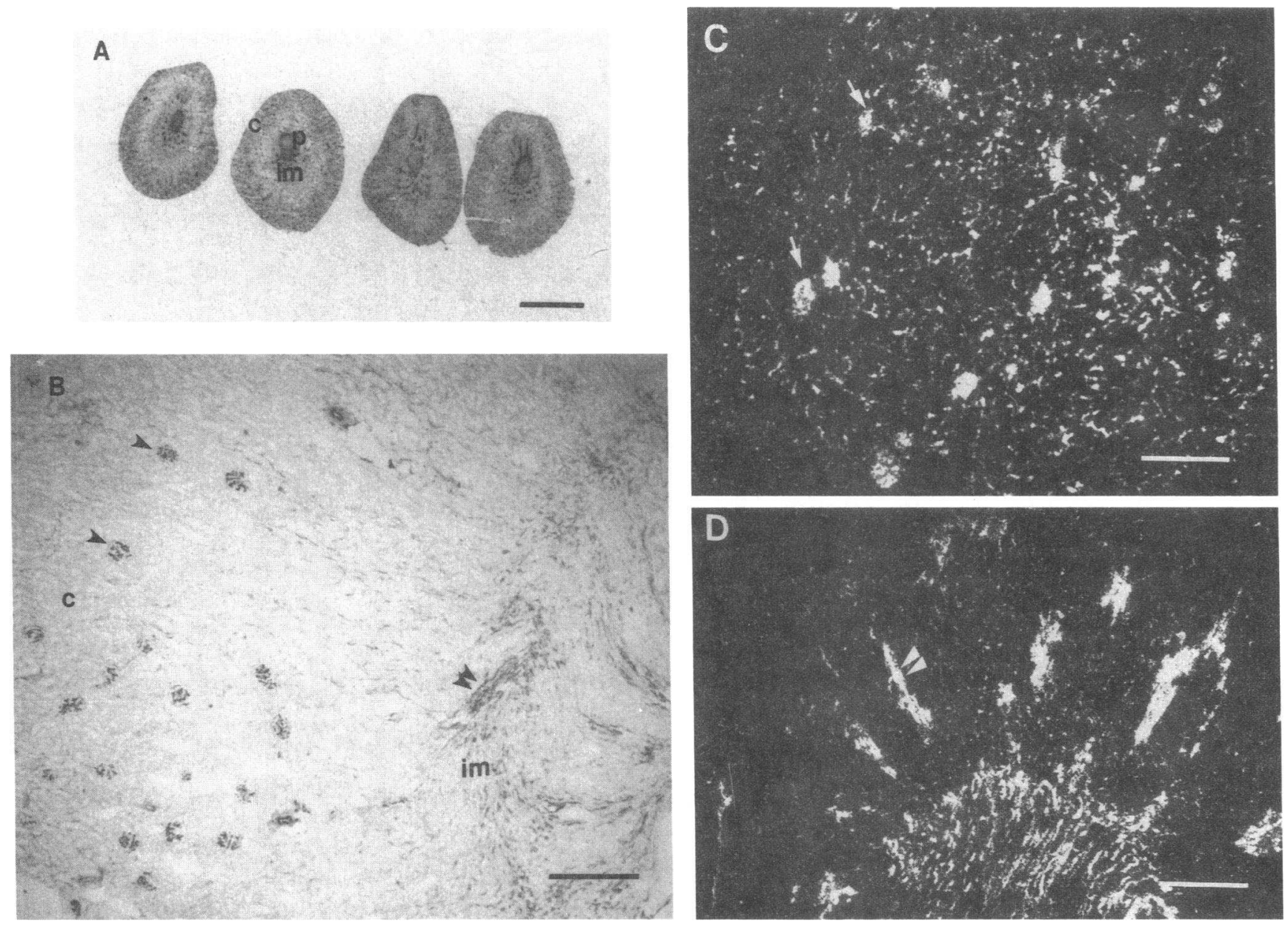

Figure 7. Binding and Factor VIII-like immunoreactivity in kidney sections. $(A)$ Autoradiograph of total binding to sections from four rat kidneys. Binding is high in the cortex $(c)$, inner medulla $(\mathrm{im})$ and papilla $(p)$ (scale bar $=20 \mathrm{~mm})$. (B) Factor-VIII immunostaining in cortex and medulla shows intense immunoreactivity corresponding to the pattern of fenestrated endothelial cells of the glomeruli (arrowheads) and medullary rays (double arrowheads). Likewise, binding exhibits a similar pattern in dark-field photomicrographs of the cortex $(C)$ and medulla $(D)$ (scale bar in $B-D=400 \mu \mathrm{m}$ ).

lining of vessels surrounding the theca and throughout the mature corpus luteum. Finally, in degenerating corpora lutea, binding of ${ }^{125}$ I-rhVEGF was limited to the periphery and no binding sites were found within the central region of lutein cell degeneration.

\section{Discussion}

The identification of binding sites for growth factors is a crucial step in understanding the biological response of cells and tissues to these factors. These studies reveal both the kinetic characteristics and distribution of binding sites, and also suggest a physiological role for VEGF. ${ }^{125}$ I-rh VEGF binding sites are distributed throughout all the tissues of the adult rat in a pattern that reflects the distinct vascularization of each organ. Quantitative autoradiographic analysis demonstrates that ${ }^{125} \mathrm{I}$ -
rhVEGF binds to these mature tissues with an affinity in the 10-50-pM range, consistent with the specificity and potency of VEGF both in vivo and in vitro (8-13). This binding is reversible and can be displaced by rhVEGF, but not by other growth factors. Finally, treatments that interfere with biological activity also prevent ${ }^{125}$ I-rhVEGF binding completely. Together, these characteristics indicate that the majority of the high affinity binding sites in tissue sections represent biologically relevant receptors for this growth factor.

Several well-characterized angiogenic growth factors such as aFGF, bFGF, and TGF $\beta$ are pleotrophic in nature. These factors have stimulatory or inhibitory effects on a variety of cell types in vitro and probably contribute in many ways to the complex interactions within tissues during development or wound healing $(1,3,4)$. In contrast, VEGF exhibits mitogenic activity in vitro that is specific for vascular endothelial cells. In

hearts of three rats. $(C)$ Bright-field photo of Factor VIII-like immunoreactivity in the microvessels of the myocardium. A few vessels are visible in longitudinal (single arrowhead) or cross section (double arrowhead). $(D)$ Dark-field photo of an adjacent section of the myocardium. $(E)$ Bright-field photo of a section through the pulmonary artery $(p a)$ and aorta $(a o)$ stained with hematoxylin and eosin. $(F)$ Dense binding is associated with the lining of both vessels (arrowheads) and with vasa vasorum (*). In contrast, few silver grains overlie the smooth muscle cells ( $s m$ ) in the media (scale bar for $B-E=200 \mu \mathrm{m}$ ). 

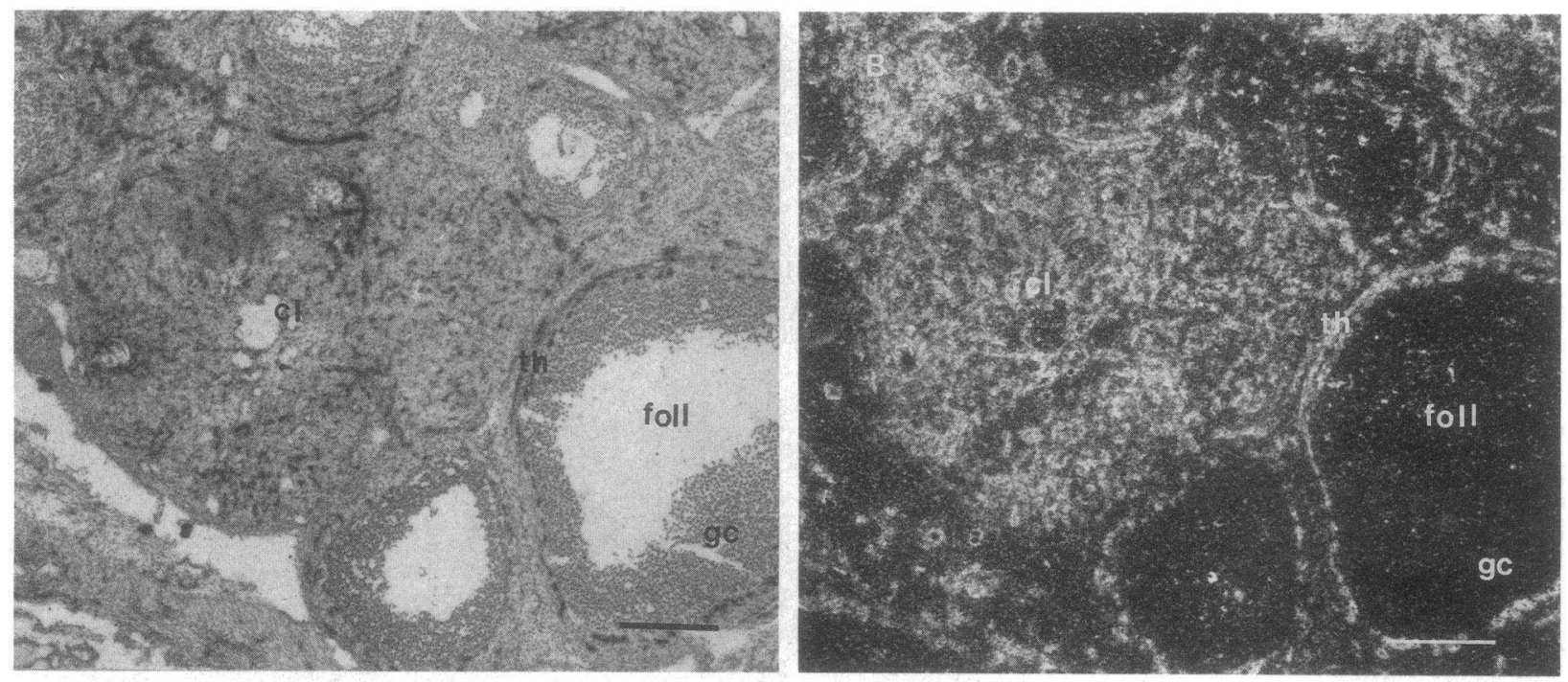

Figure 8. Total binding of ${ }^{125} \mathrm{I}-\mathrm{rhVEGF}$ to the dynamic vasculature of the ovary. $(A)$ Bright-field photo of hematoxylin-stained rat ovary section, showing the developing follicles ( $f o l l)$ with granulosa cells $(g c)$, and a mature corpus leuteum $(c l)$. The heavily vascularized theca externa $(t h)$ surrounds the developing follicles. $(B)$ Dark-field photo of the same section shows intense binding in the capillaries of the corpus leuteum and theca, and the absence of binding in the granulosa cells (scale bars $=200 \mu \mathrm{m}$ ).

the present study, the ubiquitous binding of ${ }^{125}$ I-rhVEGF to both capillaries and larger vessels, but not to nonendothelial cell types, provides the first evidence that this target-cell specificity can be extended to endothelial cells in tissues as well. Although we cannot exclude the possibility that cell types that were not in these sections, such as circulating blood cells, may also bind to VEGF in vivo or that VEGF may bind to nonendothelial cells in nonphysiological conditions (38), the available evidence indicates that VEGF activity and binding are specific for endothelial cells.

Because VEGF $_{165}$ is a heparin-binding protein, it was of interest to determine if some of the binding observed in these sections was to heparin proteoglycans or basement membranes rather than to VEGF receptors. In these conditions, excess heparin did not reduce either the specific (rhVEGF-displaceable) or nonspecific binding of the radioligand to sites in tissue sections from brain, pancreas, or heart. Furthermore, there was no displacement by excess concentrations of bFGF or PDGF, both of which bind to heparin. These data indicate that binding to heparin sites is probably insignificant with very low concentrations $(<100 \mathrm{pM})$ of labeled ligand and long $(>20 \mathrm{~min})$ postwash times. However, the contribution of VEGF binding to low affinity heparin sites in physiological conditions is unknown.

Target-cell specificity is likely to be an important characteristic of a factor that contributes to the maintenance of the endothelium or blood vessel growth in normal conditions. Perhaps not surprisingly, VEGF binding sites are found on the growing vessels within the ovary. However, VEGF binding sites are also tonically expressed in vessels that are not actively involved in angiogenesis. The uniform presence of VEGF binding sites also parallels the continual expression of VEGF mRNA in most adult tissues as detected by in situ hybridization studies. Previous studies have shown that the mature VEGF protein can be secreted and would thus be available to the surrounding endothelial cells in physiological conditions. Therefore, in addition to initiating new vessel growth, VEGF appears to be available for maintaining the vascular endothelium.
An especially high density of binding sites is found in association with the endothelial lining of the heart valves. These highly dynamic structures are constantly subjected to the shear forces of blood flow under high pressures. Furthermore, the integrity of the endothelial lining is essential to prevent such conditions as thrombosis or endocarditis $(39,40)$. The presence of high affinity binding sites in these regions emphasizes that VEGF may be important for continual repair and maintenance in regions that are susceptible to endothelial erosion.

VEGF is now known to belong to a family of polypeptides with different molecular and biological characteristics. By alternative splicing of mRNA, human VEGF can exist in four molecular forms having 121, 165, 189, or 206 amino acids, of which the 165 amino acid is the most abundant $(13,41)$. The biological significance of these different forms is not yet understood. The 165 and 121 amino acid species are both efficiently secreted by cells, as assessed by immunoprecipitation studies and bioactivity in the conditioned medium of transfected cells (41). Therefore, these forms of VEGF are most likely to be available in physiological conditions.

In contrast to $\mathrm{VEGF}_{121}$ and $\mathrm{VEGF}_{165}$, the two longer forms of VEGF appear to be mostly cell associated, despite the presence of an identical signal sequence. The information required to remain cell associated appears to be encoded within an insertion of 24 amino acids. This region is highly enriched in basic residues, and is homologous to exon 6 of PDGF-A (42). The sequence of $\mathrm{VEGF}_{189}$ is the same as that reported for human vascular permeability factor (VPF), a protein identified from tumor cell lines on the basis of its ability to induce vascular leakage and protein extravasation $(43,44)$. Those findings suggested that the expression of VPF by tumors could be responsible for the abnormal permeability properties of tumor vessels and the accumulation of ascites fluid. Recent observations indicate that all four molecular species of VEGF can promote dye extravasation when applied in a guinea pig skin permeability assay (41). However, the present findings show that in physiological conditions, the more abundant form of VEGF $\left(\mathrm{VEGF}_{165}\right)$ is probably not responsible for regulating permeabil- 
ity and protein extravasation directly. ${ }^{125}$ I-rhVEGF binding sites are found in permeable capillaries (i.e., kidney glomeruli) as well as in capillaries with tight junctions (i.e., brain). Likewise, VEGF mRNA is also consistently detected around both types of microvessels. Future studies, comparing the binding characteristics and the biological activities of these proteins may help to determine if the four molecular species can act at the same, or related, receptors in normal or transformed cells and tissues.

\section{Acknowledgments}

The authors thank Stan Hansen for cutting whole body sections, and Michael Cronin and Richard Vandlen for helpful comments and suggestions during the study.

\section{References}

1. Folkman, J., and M. Klagsbrun. 1987. Angiogenic factors. Science (Wash. DC). 243:442-447.

2. Klagsbrun, M., and D. B. Rifkin. 1987. Angiogenesis: Mechanisms and Pathology. Cold Spring Harbor Laboratory, Cold Spring Harbor, New York.

3. Gimenez-Gallego, G., J. Rodkey, C. Bennett, M. Rios-Candelore, J. DiSalvo, and K. Thomas. 1985. Brain-drived acidic fibroblast growth factor: complete amino acid sequence and homologies. Science (Wash. DC). 230:1385-1388.

4. Gospodarowicz, D., N. Ferrara, L. Schweigerer, and G. Neufeld. 1987. Structural characterization and biological functions of fibroblast growth factor. Endocr. Rev. 8:95-114.

5. Ishikawa, F., K. Miyazono, U. Hellman, H. Drexler, C. Wernstedt, K. Hagawara, K. Usuki, F. Takaku, W. Risau, and C. -H. Heldin. 1989. Identification of angiogenic activity and the cloning and expression of platelet-derived endothelial cell growth factor. Nature (Lond.). 338:557-562.

6. Walter, P., and G. Blobel. 1981. Translocation of proteins across the endoplasmic reticulum. III. Signal recognition protein (SRP) causes signal sequencedependent and site-specific arrest of chain elongation that is released by microsomal membranes. J. Cell Biol. 91:557-561.

7. Vlodavsky, I., J. Folkman, R. Sullivan, R. Fridman, R. Ishai-Michaeli, J. Sasse, and M. Klagsburn. 1987. Endothelial cell-derived basic fibroblast growth factor: synthesis and deposition into subendothelial extracellular matrix. Proc. Natl. Acad. Sci. USA. 84:2292-2296.

8. Ferrara, N., and W. J. Henzel. 1989. Pituitary follicular cells secrete a novel heparin-binding growth factor specific for vascular endothelial cells. Biochem. Biophys. Res. Commun. 161:851-858.

9. Levy, A., R. Tamargo, H. Brem, and D. Nathans. 1989. An endothelial cell growth factor from the mouse neuroblastoma cell line NB41. Growth Factors. 2:9-19.

10. Plouet, J., J. Schilling, and D. Gospodarowicz. 1989. Isolation and characterization of a newly identified endothelial cell mitogen produced by AtT-20 cells. EMBO (Eur. Mol. Biol. Organ.) J. 8:3801-3806.

11. Rosenthal, R., J. F. Megyesi, W. J. Henzel, N. Ferrara, and J. Folkman. 1990. Conditioned medium from mouse sarcoma 180 cells contains vascular endothelial growth factor. Growth Factors. 4:53-59.

12. Conn, G., M. L. Bayne, D. D. Soderman, P. W. Kwok, K. A. Sullivan, T. M. Palisi, D. A. Hope, and K. A. Thomas. 1990. Amino acid and cDNA sequences of a vascular endothelial cell mitogen that is homologous to plateletderived growth factor. Proc. Natl. Acad. Sci. USA. 87:2628-2632.

13. Leung, D., G. Cachianes, W. -J. Kuang, D. V. Goeddel, and N. Ferrara. 1989. Vascular endothelial growth factor is a secreted angiogenic mitogen. Science (Wash. DC). 246:1306-1309.

14. Ferrara, N., D. Leung, and H. S. Phillips. 1990. Molecular characterization and distribution of vascular endothelial growth factor. In Neuroendocrine Perspectives. E. E. Muller and R. M. MacLeod, editors. Springer-Verlag, New York Inc., New York. 123-157.

15. Phillips, H. S., J. Hains, D. W. Leung, and N. Ferrara. 1990. Vascular endothelial growth factor is expressed in rat corpus luteum. Endocrinology. 127:965-967.

16. Plouet, J., and H. Moukadiri. 1990. Specific binding of vasculotropin to bovine brain capillary endothelial cells. Biochimie. 72:51-55.

17. Plouet, J., and H. Moukadiri. 1990. Characterization of the receptor to vasculotropin on bovine adrenal cortex-derived capillary endothelial cells. $J$. Biol. Chem. 265:22071-22074.

18. Vaisman, N., D. Gospodarowicz, and G. Neufeld. 1990. Characterization of the receptors for vascular endothelial growth factor. J. Biol. Chem. 265:1946119466.

19. Plouet, J., H. Moudakiri, and C. Favard. 1991. Synthesis of vasculotropin/ VEGF by cultured cells: a paracrine growth factor. J. Cell Biochem. 15F:318. (Abstr.)

20. Madri, J. A., L. Bell, M. Mark, J. R. Merwin, C. Basson, and C. Prinz. 1991. Effects of soluble factors and extracellular matrix components on vascular cell behavior in vitro and in vivo: models of de-endothelialization and repair. $J$. Cell Biochem. 45:123-130.

21. Leslie, F. M., and C. A. Altar. 1988. Receptor Localization: Ligand Autoradiography. Alan R. Liss Inc., New York.

22. Aggarwal, B. B., T. E. Eesalu, and P. E. Hass. 1985. Characterization of receptors for human tumor necrosis factor and their regulation by $\gamma$-interferon. Nature (Lond.). 318:665-667.

23. Gospodarowicz, D., S. Massoglia, J. Cheng, and D. K. Fujii. 1986. Effect of fibroblast growth factor and lipoproteins on the proliferation of endothelial cells derived from bovine adrenal cortex, brain cortex, and corpus luteum capillaries. J. Cell Physiol. 127:121-136.

24. Connolly, D. T., M. B. Knight, N. K. Karakas, A. J. Wittwer, and J. Feder. 1986. Determination of the number of endothelial cells in culture using an acid phosphatase assay. Anal. Biochem. 152:136-140.

25. Hansen, S. E. 1990. Radiofluorography: a method for rapid whole body autoradiography. J. Histotechnol. 13:283-285.

26. Cuatrecasas, P., and M. D. Hollenberg. 1980. Membrane receptors and hormone action. Adv. Protein Chem. 30:251-451.

27. Altar, C. A., R. J. Walter, K. A. Neve, and J. F. Marshall. 1984. Computerassisted video analysis of ${ }^{3} \mathrm{H}$-spiroperidol autoradiography. J. Neurosci. Methods. 10:173-178.

28. Unnerstall, J. R., D. L. Niehoff, M. J. Kuhar, and J. M. Palacios. 1982 Quantitative receptor autoradiography using $\left[{ }^{3} \mathrm{H}\right]$ Ultrofilm: application to multiple bensodiazepine receptors. J. Neurosci. Methods. 6:59-63.

29. Rodbard, D., and J. E. Jewald. 1970. Computer analysis of radioligand assay and radioimmunoassay data. Acta Endocrinol. 147:79-103.

30. Munson, P. J., and D. Rodbard. 1980. Ligand: a versatile computerized approach for characterization of ligand-binding systems. Anal. Biochem. 107:220-239.

31. Moyer, C. F., P. A. Dennis, G. Majno, and I. Joris. 1988. Venular endothelium in vitro: isolation and characterization. In Vitro (Rockville). 24:359-368.

32. Mukai, K., J. Rosai, and W. H. C. Burgdorf. 1980. Localization of factor VIII-related antigen in vascular endothelial cells using an immunoperoxidase method. Am. J. Surg. Pathol. 4:273-276.

33. Hsu, S. M., L. Rane, and H. Fanger. 1981. Use of avidin-biotin peroxidase complex in immunoperoxidase techniques. J. Histochem. Cytochem. 29:577580.

34. Li, B., J. Winer, N. Ferrara, and K. J. Kim. 1991. Monoclonal antibodies to recombinant human vascular endothelial growth factor (rHuVEGF). J. Cell Biochem. CF417:251.(Abstr.)

35. Weiss, L. 1988. Cell and Tissue Biology. Urban \& Schwarzenberg, Inc., Baltimore.

36. Hebel, R., and M. W. Stromberg. 1986. Anatomy and Embryology of the Laboratory Rat. BioMed Verlag Worthsee, Worthsee, Germany.

37. Bassett, D. L. 1943. The changes in the vascular pattern of the ovary of the albino rat during the estrous cycle. Am. J. Anat. 73:251-291.

38. Clauss, M., M. Gerlach, H. Gerlach, J. Brett, F. Wang, D. T. Connolly, and D. Stern. 1990. Vascular permeability factor: A tumor-derived polypeptide that induces endothelial cell and monocyte procoagulant activity, and promotes monocyte migration. J. Exp. Med. 172:1535-1545.

39. Lepeschkin, E. 1952. On the relation between the site of valvular involvement in endocarditis and the blood pressure resting on the valve. Am. J. Med. Sci. 224:318-329.

40. Reidy, M. A., and S. M. Schwartz. 1981. Endothelial regeneration. III. Time course of intimal changes after small injury to rat aortic endothelium. Lab. Invest. 44:301-303.

41. Houck, K. A., N. Ferrara, J. Winer, and D. W. Leung. 1991. The vascular endothelial growth factor family: identification of a fourth molecular species and characterization of alternative splicing of RNA. Molec. Endocrinol. In press.

42. Betsholtz, C., F. Rorsman, B. Westermark, A. Ostman, and C. -H. Heldin. 1990. Analogous alternative splicing. Nature (Lond.). 344:299-301.

43. Senger, D. R., S. J. Galli, A. M. Dvorak, C. A. Perruzzi, V. S. Harvey, and H. F. Dvorak. 1983. Tumor cells secrete a vascular permeability factor that promotes accumulation of ascites fluid. Science (Wash. DC). 219:983-985.

44. Keck, P. J., S. D. Hauser, G. Krivi, K. Sanzo, T. Warren, J. Feder, and D. T. Connolly. 1989. Vascular permeability factor, an endothelial cell mitogen related to PDGF. Science (Wash. DC). 246:1309-1312. 